\title{
A PERÍCIA PRÉVIA COMO REQUISITO PARA O DEFERIMENTO DA RECUPERAÇÃO JUDICIAL E A MITIGAÇÃO DO PRINCÍPIO DA PRESERVAÇÃO DA EMPRESA
}

Alcides Wilhelm ${ }^{1}$

\section{RESUMO}

O presente artigo tem por objetivo analisar a exigência pelos Juízes que atuam em casos de insolvência da perícia prévia como requisito para o deferimento do processamento da recuperação judicial. Trata-se de medida que visa constatar, por intermédio de um expert, alguns pontos relacionados à empresa em crise que busca o socorro judicial para manter suas atividades. Visa identificar se a documentação exigida para o ingresso do pedido de recuperação está de acordo com o que determina a Lei de Recuperação de Empresas e Falências (LREF), se a sociedade empresária tem condições de se recuperar, gerando empregos, tributos, produtos, serviços, enfim, produzindo riquezas, bem como identificar possíveis fraudes a credores, evitando, assim, a utilização do instituto da recuperação judicial por empresas inviáveis. Porém, por mais nobres que pareçam ser os objetivos da perícia prévia, este requisito, que não encontra respaldo legal, e que vem sendo utilizado com frequência pelos tribunais, causa sérios problemas para a devedora, que vê protelado o deferimento de seu pedido de recuperação judicial e dos pedidos liminares que permeiam esse tipo de procedimento, causando uma demora desnecessária para que a empresa obtenha a proteção legal a ela destinada. A decisão que determina a realização da perícia prévia é, prima facie, ativismo judicial, interferindo o judiciário diretamente na atividade do legislador. A metodologia utilizada foi o estudo bibliográfico e documental.

Palavras chave: Insolvência; Recuperação Judicial; Perícia Prévia; Ativismo Judicial.

\section{THE PRIOR EXPERTISE AS REQUIREMENT FOR THE DEFERRING OF JUDICIAL RECOVERY AND THE MITIGATION OF THE PRINCIPLE OF THE PRESERVATION OF THE COMPANY}

\begin{abstract}
The purpose of this article is to analyze the requirement by Judges acting in cases of insolvency, prior expertise as a requirement for the approval of judicial recovery proceedings. It is a measure that aims to establish, through an expert, some points related to the company in crisis that seeks judicial help to maintain its activities. It aims to identify if the documentation required for the application for recovery is in accordance with the insolvency law (LREF), if the company is able to recover, generating jobs, taxes, products, services, ultimately producing wealth, as well as identifying possible frauds to creditors, thus avoiding the use of the institute of judicial recovery by non-viable companies. However, no matter how noble it may seem to be the objectives of the prior examination, this requirement, which is not legally

\footnotetext{
${ }^{1}$ Advogado. Mestrando em Direito Empresarial e Cidadania pelo Centro Universitário Curitiba (Unicuritiba). Artigo como requisito parcial para aprovação na matéria Crise da Jurisdição, Efetividade e Plenitude Institucional do professor Fernando Knoerr. Contato: alcides@wilhelm.adv.br
}

Revista Brasileira de Direito Empresarial | e-ISSN: 2526-0235 | Goiânia | v. 5 | n. 1 | p. 57 - 80 | Jan/Jun. 2019. 
supported and is being used frequently by the courts, causes serious problems for the debtor, who finds it delayed to grant her recovery request court proceedings and preliminary injunctions, which permeate this type of procedure, causing unnecessary delay for the company to obtain the legal protection intended for it. The decision that determines the accomplishment of the prior investigation is, prima facie, judicial activism, interfering the judiciary directly in the activity of the legislator. The methodology used was the bibliographic and documentary study.

Key-words: Insolvency; Judicial Recovery; Prior Expertise; Judicial Activism.

\section{INTRODUÇÃO}

Com o advento da Lei n. 11.101, de 9 de fevereiro de 2005, a nova Lei de Recuperação de Empresas e Falências (LREF), que passou a regulamentar a recuperação judicial, a extrajudicial e a falência do empresário e da sociedade empresária no ordenamento brasileiro, muitas questões afloraram e foram tomando forma com as decisões judiciais, individuais e colegiadas, construindo-se uma jurisprudência sobre temas relacionados à sua aplicação.

O espírito da norma está contido no artigo 47 da Lei de Recuperação de Empresas, quando determina que a recuperação judicial tem por objetivo viabilizar a superação da situação de crise econômico-financeira da sociedade empresária, permitindo a manutenção da fonte produtora, do emprego dos trabalhadores, dos interesses dos credores, promovendo a preservação da empresa e sua função social e, ainda, estimulando a atividade econômica.

Não podemos olvidar que a nova lei de insolvência brasileira trouxe uma evolução significativa em relação ao vetusto Decreto-lei n. 7.661, de 21 de junho de 1945, conhecida como "Lei de Falências", cujo nome já era um indicativo de seu real objetivo, regulamentar à falência.

Com a brutal evolução ocorrida, que aproximou a legislação brasileira dos diplomas legais das principais economias mundiais, abriu-se um vasto espaço para a interpretação jurídica, trazendo à baila um novo ambiente operacional para a insolvência.

Dentre muitas situações que ainda suscitam interpretações, temos o caso da perícia prévia como um requisito para o deferimento do processamento da recuperação judicial. Trata-se de exigência não positivada, sendo construída hermeneuticamente por alguns Juízes altamente especializados no exercício de suas atividades na seara recuperacional, cuja 
finalidade seria averiguar a regularidade da documentação acostada à petição inicial, bem como as reais condições de recuperação da empresa em crise, afastando a possibilidade do instituto da recuperação judicial ser utilizado de forma indevida.

Nesta senda, a exigência da perícia prévia é absolutamente descabida e ilegal, acarretando uma série de problemas para as empresas que buscam, na proteção legal do instituto da recuperação judicial, a preservação das suas atividades.

Com a importância que a atividade empresária adquiriu ao longo do tempo, sendo ela essencial para o desenvolvimento da sociedade e para a distribuição de riquezas, sua manutenção é dever do Estado, que precisa adotar políticas que viabilizem seu crescimento, gerando um ambiente de negócios saudável e com normas legais que tragam segurança jurídica.

Nesse contexto, a perícia prévia instituída pelo Poder Judiciário vem de encontro ao princípio da preservação da empresa, amplamente difundido em nosso sistema jurídico, seja pela Constituição Federal de 1988, nossa lex mater, bem como por outras normas de hierarquia inferior.

O presente estudo demonstrará, de forma fundamentada, a ilegalidade cometida pelos Juízes ao exigirem a perícia prévia para a tomada de decisão quanto ao deferimento ou não do processamento da recuperação, praticando o que atualmente conhecemos por ativismo judicial.

A pesquisa será desenvolvida utilizando a metodologia de estudo bibliográfico e documental, com consulta a obras literárias de doutrinadores, artigos, notícias, decisões de tribunais, dentre outros, sendo dividida da seguinte forma: (i) Introdução; (ii) A preservação da empresa no ordenamento jurídico brasileiro; (iii) Os limites da interpretação jurídica; (iv) A interpretação jurídica aplicada à perícia prévia pelos magistrados - Um caso de ativismo judicial; (v) A melhor interpretação jurídica; e (vi) Considerações finais.

\section{A PRESERVAÇÃO DA EMPRESA NO ORDENAMENTO JURÍDICO BRASILEIRO}

Antes de ingressar diretamente no tema deste tópico sobre a preservação da empresa, importante conhecer alguns conceitos de doutrinadores sobre o que é a empresa, afinal é em 
torno dela que orbita nosso objeto de estudo, a perícia prévia como requisito para o deferimento da recuperação judicial das empresas em crise, bem como a sua preservação.

Ronald H. Coase, por exemplo, busca a explicação para a existência das empresas na economia, argumentado que a produção pode ser realizada de forma totalmente descentralizada, por meio de contratos entre indivíduos, os quais geram custos relativos à participação nessas transações (COASE, 2017, p. 7). Porém, sempre surgirão firmas para organizar essas transações quando os custos puderem ser menores do que aquelas transações individuais de mercado. Em síntese, argumenta que, para facilitar o fornecimento de bens e serviços, buscam-se na empresa (firma) os mecanismos de redução dos custos de transação.

Essa assertiva, que foi mencionada há mais de 50 anos, continua atual, pois é possível identificar esse movimento em busca da redução dos custos de transação a todo momento pelas empresas, seja pela constituição de novos negócios ou em casos de fusões e aquisições, cujas sinergias levam a resultados semelhantes.

Sztajn (2010, p. 158), em linha semelhante à de Coase, conceitua empresa da seguinte forma:

\begin{abstract}
Firmas são organizações que transformam insumos (inputs) em bens (outputs). São feixes de contratos mediante os quais se organizam a produção e a distribuição de bens nos mercados. As firmas são necessárias para diminuir custos de contratação que recaem sobre o empreendedor por conta de imperfeições ou falhas de mercado. Quer dizer, se para produzir fosse necessário contratar pontual e reiteradamente nos mercados, seria preciso encontrar, a cada um desses momentos, fornecedor que oferecesse o menor preço e tivesse o insumo para pronta entrega; que o prestador de serviços, além de habilitado a executar a tarefa, estivesse disponível e, também ele, cobrasse o menor valor; que o comprador, pronto para receber o bem, estivesse disposto a pagar o maior preço; e que, em toda essa cadeia, as diversas etapas se seguissem, umas às outras, com segurança. (SZTAJN, 2010.)
\end{abstract}

Nos conceitos estabelecidos por Coase e Sztajn, é possível concluir sobre a relevância que a empresa possui para a sociedade, pois é por intermédio dela que bens e serviços, em grande quantidade e diversidade, são disponibilizados a preços acessíveis ao consumidor, que é um dos principais beneficiários da redução dos custos de transação pela organização das atividades em sociedades empresárias.

É possível observar também que, em torno de uma empresa, orbitam uma infinidade de outros benefícios de ordem econômica e social, sendo ela um elemento essencial para o desenvolvimento e o bem-estar da sociedade. É por seu intermédio que empregos são gerados, tributos cobrados, Estados financiados, programas sociais executados, patentes criadas, evoluções tecnológicas desenvolvidas, entre outros tantos exemplos possíveis de citar. Em 
síntese, é possível concluir que a estabilidade e evolução da sociedade moderna ocorrem, especialmente, dentro das organizações empresariais.

Dada a importância da empresa, a Constituição Federal de 1988 trouxe diversas regras e princípios implícitos sobre a necessidade de sua preservação. O artigo 170, v. g., determina que a ordem econômica está fundada na valorização do trabalho e na livre iniciativa, assegurando a todos existência digna a fim de proporcionar justiça social. Este artigo está inserido em capítulo destinado à Ordem Econômica e Financeira, sendo a valorização do trabalho e a livre iniciativa princípios gerais.

Notadamente, podemos concluir que a ordem econômica preconizada na Constituição Federal é interpretada sob a ótica das sociedades empresárias, das empresas, que são células que mantêm o tecido econômico em funcionamento. Corroborando com esse entendimento, Warde Júnior dispôs que "a empresa surgiu, portanto, como técnica de regulação de porção abrangente do fenômeno econômico" (WARDE JÚNIOR, 2016, p. 36).

Outros princípios que tratam da preservação da empresa, direta ou indiretamente, estão inseridos nos incisos do artigo 170, dentre eles, especialmente, o "tratamento favorecido para as empresas de pequeno porte constituídas sob as leis brasileiras e que tenham sua sede e administração no País" (inciso IX); a "busca do pleno emprego" (inciso VII); a "livre concorrência" (inciso IV); a "função social da propriedade" (inciso III). Todos são vinculados aos princípios traçados no caput do referido artigo $^{2}$, e indiretamente à preservação da empresa, princípio este de ordem implícita.

A Constituição Federal de 1988 também fez menção à necessidade da preservação das empresas em diversos outros dispositivos, como, v. g., no artigo $1^{\circ}$, inciso $\mathrm{IV}^{3}, 5^{\circ}$, inciso $\mathrm{XIII}^{4}$, e do art. $6^{05}$. O modelo econômico (capitalista) e social (dignidade da pessoa humana) adotado reforça a importância das empresas para o desenvolvimento almejado.

\footnotetext{
${ }^{2}$ I - soberania nacional; II - propriedade privada; III - função social da propriedade; V - defesa do consumidor; VI - defesa do meio ambiente, inclusive mediante tratamento diferenciado conforme o impacto ambiental dos produtos e serviços e de seus processos de elaboração e prestação; VII - redução das desigualdades regionais e sociais.

${ }^{3}$ Art. $1^{\mathrm{o}}-(\ldots) \mathrm{IV}$ - os valores sociais do trabalho e da livre iniciativa.

${ }^{4}$ Art. $5^{\circ}-(\ldots)$ XIII - é livre o exercício de qualquer trabalho, ofício ou profissão, atendidas as qualificações profissionais que a lei estabelecer.

${ }^{5}$ Art. $6^{\circ}$ São direitos sociais a educação, a saúde, a alimentação, o trabalho, a moradia, o transporte, o lazer, a segurança, a previdência social, a proteção à maternidade e à infância, a assistência aos desamparados, na forma desta Constituição.
} 
Eros $\mathrm{Grau}^{6}$, sobre os princípios constitucionais da ordem econômica tem a dizer:

108. Princípio a seguir enunciado, no elenco daqueles que constituem os princípios da ordem econômica - além da redução das desigualdades regionais e sociais, do qual anteriormente cogitei é o da busca do pleno emprego (art. 170, VIII). Princípio constitucional impositivo (Canotilho), cumpre também dupla função; como objetivo particular a ser alcançado, assume igualmente, a feição de diretriz (Dworkin) norma-objetivo - dotada de caráter constitucional conformador, a justificar a reinvindicação pela realização de políticas públicas.

Em outros termos - "expansão das oportunidades de emprego produtivo" - esse princípio já fora contemplado entre aqueles da ordem econômica na Emenda Constitucional n. 1/69, no art. 160, VI. Em razão de ser esse, o imediatamente acima transcrito, o seu enunciado, tomava-se-o, em regra, como se estivesse referido, exclusivamente, ao pleno emprego do fator trabalho.

"Expansão de oportunidades de emprego produtivo" e, corretamente, "pleno emprego" são expressões que conotam o ideal keynesiano de emprego pleno de todos os recursos e fatores da produção. O princípio informa o conteúdo ativo do princípio da função social da propriedade. A propriedade dotada de função social obriga o proprietário ou titular do poder de controle sobre ela ao exercício desse direito-função (poder-dever), até para que se esteja a realizar o pleno emprego.

Não obstante, consubstancia também, o princípio da busca do pleno emprego, indiretamente, uma garantia para o trabalhador, na medida em que está coligado ao princípio da valorização do trabalho humano e reflete efeitos em relação ao direito social ao trabalho (art. $6^{\circ}$, caput). (GRAU, 2017, p. 249-250.)

Warde Júnior (2016, p. 73), ao tratar da importância da empresa na ordem econômica, manifestou que "a empresa é, como veremos, um dos instrumentos jurídicos à disposição do Estado, no contexto de sua atuação nos sistemas econômicos (...)”.

Castro, ao versar sobre o tema, dispôs que "a Constituição Federal de 1988 instaurou, portanto, uma ordem econômica, fundada na valorização do trabalho humano e na livre iniciativa, observada a função social da propriedade e da busca do pleno emprego" (CASTRO, 2010, p. 39).

Já Horta, sobre a Constituição Federal (CF/88):

A Ordem Econômica e Financeira não é ilha normativa apartada da Constituição. É fragmento da Constituição, uma parte do todo constitucional e nele se integra. A interpretação, a aplicação e a execução dos preceitos que a compõem reclamam o ajustamento permanente das regras da Ordem Econômica e Financeira às disposições do texto constitucional que se espraiam nas outras partes da Constituição. A Ordem Econômica e Financeira é indissociável dos princípios fundamentais da República Federativa e do Estado Democrático de Direito. Suas regras visam atingir os objetivos fundamentais que a Constituição colocou na meta constitucional da República Federativa. A Ordem Econômica e Financeira é, por isso, instrumento para construção de uma Sociedade livre, justa e solidária. É a fonte das normas e decisões que permitirão à República garantir o desenvolvimento nacional, erradicar a pobreza, a marginalização, reduzir as desigualdades sociais e

\footnotetext{
${ }^{6}$ Os grifos que se seguem são do autor.
} 
promover o bem de todos, sem preconceitos de origem, raça, sexo, cor, idade e quaisquer outras formas de discriminação". (HORTA, 1995, p. 301.)

Da análise sistemática da Constituição Federal de 1988, que adota um modelo econômico capitalista que leve ao bem-estar social, verifica-se que a empresa é elemento essencial para que o Estado cumpra seu papel dentro dos parâmetros constitucionalmente programados, e a preservação da empresa é dever-direito de todos para que os objetivos sejam alcançados.

Outros diplomas legais também contemplam o princípio da preservação da empresa, como, v. g., o Código Civil de 2002. Mesmo em se tratando de um projeto cuja proposta tem mais de 30 anos, ou seja, nascido bem antes da Constituição de 1988, de cunho eminentemente patrimonialista, o novo código deve ser lido a partir das premissas da Constituição Federal, que apresenta viés social, tendo na pessoa humana o centro de seus interesses.

Castro, sobre a interpretação do Código Civil à luz da Constituição, dispôs o seguinte:

\begin{abstract}
Desta forma, na medida em que se busca demonstrar que o princípio da preservação da empresa se constitui no pilar do Direito de Empresa no Código Civil, há de esclarecer que esse pensamento implica visualizar o Código como diploma aberto que integra a unidade do sistema jurídico, cuja leitura deve ser feita a partir da Constituição Federal (...). (CASTRO, 2010, p. 132-133.)
\end{abstract}

Entre várias disposições do Código Civil que visam preservar a empresa, podemos destacar o artigo 970, que está em consonância com o artigo 170, inciso IX, da Constituição Federal de 1988, quando determina que a lei assegurará tratamento favorecido, diferenciado e simplificado ao empresário rural e ao pequeno empresário, quanto à inscrição e aos efeitos daí decorrentes.

$\mathrm{Grau}^{7}$, sobre o artigo 170, inciso IX, da Constituição Federal de 1988 infere:

O último dos chamados princípios da ordem econômica é o do tratamento favorecido para as empresas de pequeno porte constituídas sob as leis brasileiras e que tenham sua sede e administração no País (art. 170, IX, na redação que lhe foi conferida pela Emenda Constitucional n. 6/95). O preceito originariamente referia tratamento favorecido para as empresas brasileiras de capital nacional de pequeno porte. Trata-se, formalmente, de princípio constitucional impositivo (Canotilho), já que a Constituição como princípio o tomou; daí o seu caráter constitucional conformador. Não consubstancia, no entanto, como os demais princípios da ordem

\footnotetext{
${ }^{7}$ Os grifos que se seguem são do autor.
} 
econômica, uma diretriz (Dworkin) ou norma-objetivo. Ainda assim, fundamenta a reivindicação, por tais empresas, pela realização de políticas públicas. De resto, está parcialmente reproduzido no preceito inscrito no art. 179. (GRAU, 2017, p. 251.)

Dentre todas as normas que visam a preservação da empresa, as quais encontram-se de forma dispersa por muitos diplomas legais, iniciando em nossa lex mater, foi na Lei $\mathrm{n}$. 11.101/05, Lei de Recuperação de Empresas e Falências, que o instituto se materializou com maior ênfase, destinando às empresas que se encontram em crise econômico-financeira legislação especial para viabilizar a sua recuperação.

A nova lei trouxe modernidade ao instituto recuperacional, deixando para trás o vetusto Decreto-lei n. 7.661/45, que possibilitava uma sobrevida às empresas em crise, mas não possuía regras legais suficientes que viabilizassem seu soerguimento, resultando na falência daquelas empresas. Entre uma legislação e outra, passaram-se 60 anos, sem grandes alterações até a entrada do novo diploma legal, indício suficiente para se concluir que o decreto-lei não atendia mais a demanda empresarial da nova economia do século XXI.

A Lei n. 11.101/05, em seu artigo 47, trouxe o espírito da nova norma, que visa, primordialmente, preservar a empresa em crise, in verbis:

Art. 47. A recuperação judicial tem por objetivo viabilizar a superação da situação de crise econômico-financeira do devedor, a fim de permitir a manutenção da fonte produtora, do emprego dos trabalhadores e dos interesses dos credores, promovendo, assim, a preservação da empresa, sua função social e o estímulo à atividade econômica. ${ }^{8}$

Lobo, ao referir-se ao instituto da recuperação judicial, argumenta:

Recuperação judicial é o instituto jurídico, fundado na ética da solidariedade, que visa sanear o estado de crise econômico-financeira do empresário e da sociedade empresária com a finalidade de preservar os negócios sociais e estimular a atividade empresarial, garantir a continuidade do emprego e fomentar o trabalho humano, assegurar a satisfação, ainda que parcial e em diferentes condições, dos direitos e interesses dos credores e impulsionar a economia creditícia, mediante a apresentação, nos autos da ação de recuperação judicial, de um plano de reestruturação e reerguimento, o qual, aprovado pelos credores, expressa ou tacitamente, e homologado pelo juízo, implica novação dos créditos anteriores ao ajuizamento da demanda e obriga a todos os credores a ela sujeitos, inclusive os ausentes, os dissidentes e os que se abstiveram de participar das deliberações da assembleia. (LOBO, et al, 2012, p. 168.) ${ }^{9}$

\footnotetext{
${ }^{8}$ Grifo nosso.

${ }^{9}$ Grifo nosso.
} 
Portanto, a importância da empresa para a sociedade hodierna é bem demonstrada pela enorme quantidade de legislação destinada à sua regulamentação, sendo ela, atualmente, um instituto de fundamental importância para a humanidade, e sua preservação é dever dos Estados na busca do desenvolvimento e da pacificação social.

\section{OS LIMITES DA INTERPRETAÇÃO JURÍDICA}

Na era contemporânea, não cabe mais ao Juiz ser apenas a "boca da lei”, conforme pregava Napoleão, relegando à atividade judicial o mero replicador do que estava escrito nos códigos, sendo a lei autossuficiente. O papel do juiz era reduzido à insignificância de declarar o direito vigente. Trata-se de uma visão do Direito ultrapassada, cabendo ao Juiz moderno ser o intérprete da lei, adequando-a às necessidades da sociedade em seu tempo.

Neste sentido, em 8 de dezembro de 1908, o Presidente Theodor Roosevelt (apud CAPEPELLETTI, 1993, p. 5), em mensagem enviada ao Congresso Americano, manifestouse, da seguinte forma:

\footnotetext{
Os principais criadores do direito (...) podem ser, e frequentemente são, os juízes, pois representam a voz final da autoridade. Toda vez que interpretam um contrato, uma relação real (...) ou as garantias do processo e da liberdade, emitem necessariamente no ordenamento jurídico partículas dum sistema de filosofia social; com essas interpretações, de fundamental importância, emprestam direção a toda atividade de criação do direito. As decisões dos tribunais sobre questões econômicas e sociais dependem da sua filosofia econômica e social, motivo pelo qual o progresso pacífico do nosso povo, no curso do século $X X$, dependerá em larga medida de que os juízes saibam fazer-se portadores duma moderna filosofia econômica e social, antes de que superada filosofia, por si mesma produto de condições econômicas superadas. (CAPPELLETTI, 1993.) . $^{10}$
}

O texto citado demonstra uma atualidade impressionante, bastando um olhar para as decisões proferidas pelos nossos tribunais. Porém, muitas delas são controvertidas e fora do contexto positivado pelo legislador. Ao Juiz, criador do direito, não lhe é permitido poderes absolutos, mas sim limitados dentro do conceito político dos checks and balances.

Obviamente que ao Juiz-intérprete há limitações que devem ser observadas, pois, caso contrário, uma anarquia seria instaurada, mesmo que involuntariamente, pelas muitas interpretações aplicadas à mesma norma.

${ }^{10}$ Os grifos são nossos. 
Barwick (apud CAPPELLETTI), em sentido semelhante, ao tratar sobre a interpretação e criação do direito:

Quando se diz - como faz o "Chief Justice" Barwick, para citar apenas exemplo recente - que a expansão do direito legislativo, no estado moderno estendida a muitíssimos domínios antes ignorados pela lei, acarretou e ainda está acarretando consigo a paralela expansão do direito judiciário, subentende-se obviamente a negação da clara antítese entre interpretação judiciária da lei e criatividade dos juízes. Encontra-se implícito, em outras palavras, o reconhecimento de que na interpretação judiciária do direito legislativo está ínsito certo grau de criatividade. $\mathrm{O}$ ponto, de resto, tornou-se explícito pelo próprio Barwick quando escreve que ainda "a melhor arte de redação das leis", e mesmo o uso das mais simples e precisa linguagem legislativa, sempre deixam, de qualquer modo, lacunas que devem ser preenchidas pelo juiz e sempre permitem ambiguidades e incertezas que em última análise, devem ser resolvidas na via judiciária. (CAPPELLETTI, 1993, p.20) ${ }^{11}$

Cappelletti, continuando, dispôs:

O verdadeiro problema, portanto, não é o da clara oposição, na realidade inexistente, entre os conceitos de interpretação e criação do direito. O verdadeiro problema é outro, ou seja, o do grau de criatividade e dos modos, limites e aceitabilidade da criação do direito por obra dos tribunais judiciários. (CAPPELLETTI, 1993, p. 21.)

(...)

Por isso, deve ser firmamente precisado que os limites substanciais não são completamente privados de eficácia: criatividade jurisprudencial, mesmo em sua forma mais acentuada, não significa necessariamente "direito livre", no sentido de direito arbitrariamente criado pelo juiz do caso concreto. (CAPPELLETTI, 1993, p. 21 e ss.) ${ }^{12}$

Nesse sentido, ao intérprete do direito cabe analisar o que está escrito e dar sentido dentro de um campo de interpretação limitado, pois, fora disso, estaria praticando ativismo judicial. Assim, não é permitido ao juiz interpretar a norma como bem entender, ou mesmo, a margem do texto legal, criar seu próprio direito. Mesmo sendo admitidas várias interpretações, elas precisam estar concisas com o sistema jurídico posto, que tem no positivismo seu alicerce.

Kelsen $^{13}$, ao tratar da interpretação da norma e sua obra prima, afirmou:

O Direito a aplicar forma, em todas estas hipóteses, uma moldura dentro da qual existem várias possibilidades de aplicação, pelo que é conforme ao Direito todo ato

\footnotetext{
11 Os grifos são nossos.

12 Os grifos são nossos.

${ }^{13}$ Os grifos a seguir são nossos.
} 
que se mantenha dentro deste quadro ou moldura, que preencha esta moldura em qualquer sentido possível.

Se por "interpretação" se entende a fixação por via cognoscitiva do sentido do objeto a interpretar, o resultado de uma interpretação jurídica somente pode ser a fixação da moldura que representa o Direito a interpretar e, consequentemente, o conhecimento das várias possibilidades que dentro desta moldura existem. (KELSEN, 2009, p. 390.)

Assim, não é permitido ao Juiz tomar o lugar do legislador, criando normas inexistentes, porém, é permitido interpretar dentro das diversas possibilidades que a norma lhe proporciona, sem com isso abandonar o primado da legalidade e a segurança jurídica.

Conhecer esse entendimento doutrinário é fundamental para a compreensão do fenômeno que vem ocorrendo em nossos tribunais, especialmente nos processos de insolvência, quanto à necessidade de perícia prévia como requisito para o deferimento do processamento da recuperação judicial.

\section{A INTERPRETAÇÃo JURídica APLICAda À PERíCIA PRÉvia PELOS MAGISTRADOS - UM CASO DE ATIVISMO JUDICIAL}

Com a entrada em vigor da Lei n. 11.101, de 9 de fevereiro de 2005, e quando da análise do pedido de recuperação judicial da sociedade empresária VASP, junto à $1^{\mathrm{a}}$ Vara de Falências e Recuperações Judiciais de São Paulo (SP), sendo este considerado o grande teste para a nova lei de insolvência brasileira, a prática de solicitar a perícia prévia teve início. Naquele momento, o Juiz titular da Vara era o Dr. Alexandre Lazzarini, que, diante da nova norma e do gigantismo da empresa solicitante do benefício legal, proferiu o seguinte despacho, in verbis:

(...) a lei 11.101/2005 é clara e quando fixa os requisitos para a postulação do processamento da recuperação judicial (art. 51), o faz considerando eles necessários para que o instituto preserve os seus princípios fundamentais (art. 47). 6) (...) em face da peculiaridade da intervenção existente e do tamanho da empresa, de cunho nacional, nomeio o advogado Alfredo Luis Kugelmas e o contador José Vanderlei Masson dos Santos, endereços em cartório, para verificarem se a devedora terá condição, e quanto tempo aproximadamente em caso positivo, para apresentar os documentos exigidos no art. 51, II e VIII, da LRF, bem como se os documentos a que se referem os incisos III e IV do mesmo art. 51, e os demais exigidos, estão formalmente em ordem e de acordo com os dados contábeis da empresa (LRF, art. $51, \S 1^{\circ}$ ), no prazo de 20 (vinte) dias. Observo que não se discute a viabilidade da recuperação judicial neste momento, mas, tão somente, a possibilidade de se preencher os requisitos legais para se obter o processamento. Assim, os ilustres peritos não devem se manifestar quanto aquele fato. Para tanto, fixo os honorários de $\mathrm{R} \$ 1.200,00$ (um mil e duzentos reais) para cada um, que deve ser depositado em 5 (cinco) dias. Deposite a devedora os honorários. 7) Após, será decidido a respeito de prazo para aditamento e quanto as 
intimações requeridas, anotando-se, porém, que as custas deverão ser recolhidas, em prazo a ser fixado. (FURTADO, 2018.) ${ }^{14}$

Observa-se pelo despacho que o intuito do juízo era confirmar, especialmente, a regularidade dos documentos exigidos pelo artigo 51 da Lei de Recuperação de Empresas e Falências, requisito esse essencial para proferir o despacho deferindo o processamento da recuperação judicial, conforme disposto em seu artigo 52, caput. Note-se que o eminente Juiz enfatizou a desnecessidade de os peritos adentrarem no mérito quanto à viabilidade econômica da recuperanda, devendo os experts analisarem apenas a regularidade documental. Nesse momento, inaugurou-se a exigência da perícia prévia.

O artigo 51 da Lei de Recuperação de Empresas e Falências (LREF) contempla todos os documentos e informações necessárias que devem ser apresentados pela empresa no ato do pedido de recuperação, in verbis:

Art. 51. A petição inicial de recuperação judicial será instruída com:

I - a exposição das causas concretas da situação patrimonial do devedor e das razões da crise econômico-financeira;

II - as demonstrações contábeis relativas aos 3 (três) últimos exercícios sociais e as levantadas especialmente para instruir o pedido, confeccionadas com estrita observância da legislação societária aplicável e compostas obrigatoriamente de:

a) balanço patrimonial;

b) demonstração de resultados acumulados;

c) demonstração do resultado desde o último exercício social;

d) relatório gerencial de fluxo de caixa e de sua projeção;

III - a relação nominal completa dos credores, inclusive aqueles por obrigação de fazer ou de dar, com a indicação do endereço de cada um, a natureza, a classificação e o valor atualizado do crédito, discriminando sua origem, o regime dos respectivos vencimentos e a indicação dos registros contábeis de cada transação pendente;

IV - a relação integral dos empregados, em que constem as respectivas funções, salários, indenizações e outras parcelas a que têm direito, com o correspondente mês de competência, e a discriminação dos valores pendentes de pagamento;

V - certidão de regularidade do devedor no Registro Público de Empresas, o ato constitutivo atualizado e as atas de nomeação dos atuais administradores;

VI - a relação dos bens particulares dos sócios controladores e dos administradores do devedor;

VII - os extratos atualizados das contas bancárias do devedor e de suas eventuais aplicações financeiras de qualquer modalidade, inclusive em fundos de investimento ou em bolsas de valores, emitidos pelas respectivas instituições financeiras;

VIII - certidões dos cartórios de protestos situados na comarca do domicílio ou sede do devedor e naquelas onde possui filial;

IX - a relação, subscrita pelo devedor, de todas as ações judiciais em que este figure como parte, inclusive as de natureza trabalhista, com a estimativa dos respectivos valores demandados.

14 Os grifos são nossos. 
Continuando, o artigo 52, caput, determina que "estando em termos a documentação exigida no art. 51 desta Lei, o juiz deferirá o processamento da recuperação judicial e, no mesmo ato (...)", ou seja, estando regular a documentação apresentada, o Juiz deverá proferir o deferimento do processamento da recuperação, não lhe sendo oportunizada qualquer outra escolha.

Por mais nobre que tenha sido a intenção do juízo, a solicitação da perícia prévia para fazer a conferência dos documentos exigidos no artigo 51 da Lei n. 11.101/05 não tem cabimento, pois ausente de previsão legal, sendo esta tarefa delegada ao Juiz pela lei.

Esse movimento pela exigência de perícia prévia tomou corpo, atualmente, pelo Excelentíssimo Juiz de Direito da $1^{\text {a }}$ Vara de Falências e Recuperação de Empresas de São Paulo, Dr. Daniel Carnio Costa, que ocupa atualmente a respectiva Vara, sendo um defensor da medida, não mais em casos excepcionais, mas de forma geral, visando, especialmente, a correta aplicação do remédio legal, ou seja, não possibilitar que empresas inviáveis se utilizem da recuperação judicial, mas tenham o tratamento que a lei oferece para esses casos, a falência, devendo fazerem jus ao benefício legal apenas as empresas plenamente recuperáveis. Segundo Costa, essa medida surgiu em 2011 quando da constatação de que alguns casos ajuizados de recuperação judicial tinham como objetivo conseguir a proteção legal (stay period), impossibilitando os credores de tomarem medidas judiciais na tentativa de reaverem seus créditos. Tratava-se de sociedades empresárias que existiam apenas formalmente, não exercendo mais suas atividades, não gerando empregos, tributos, circulação de produtos ou serviços, tampouco tributos ou riquezas. Tais situações eram detectadas quando da primeira visita do Administrador Judicial à empresa (COSTA, 2018).

Daniel Costa, para justificar a necessidade de perícia prévia, dispôs:

A perícia prévia consiste em uma constatação informal determinada pelo magistrado
antes da decisão de deferimento do processamento da recuperação judicial, com a
finalidade de averiguar a regularidade da documentação técnica que acompanha a
petição inicial, bem como as reais condições de funcionamento da empresa
requerente, de modo a conferir ao magistrado condições mais adequadas para
decidir sobre o deferimento ou não do início do processo de recuperação judicial.
Trata-se de providência que visa garantir a aplicação regular e efetiva da
recuperação judicial em defesa da preservação dos interesses público, social e
dos credores. A providência judicial não decorre de artigo expresso de lei, mas
da interpretação adequada do artigo 52 da lei 11.101/05. (COSTA, 2018.)

15 Os grifos são nossos. 
É possível verificar que a interpretação utilizada para justificar a perícia prévia se dá pela correta aplicação do artigo 52 da Lei n. 11.101/05, bem como pela correta utilização do remédio legal, visando sempre a busca pelos melhores resultados no interesse dos credores, do devedor e da sociedade em geral, independentemente de previsão legal.

Trata-se da teoria hermenêutica da superação do dualismo pendular, que visa proteger todos os polos da relação de direito material, não apenas um deles.

\section{A MELHOR INTERPRETAÇÃO JURÍDICA}

Para justificar a desnecessidade da perícia prévia como requisito para o deferimento do processamento da recuperação judicial, será procedida a análise a partir dos mesmos artigos 51 e 52 da Lei n. 11.101/05, que tratam da documentação necessária para instruir o processo de recuperação e do deferimento do processamento da recuperação judicial, respectivamente, bem como de outros artigos da mesma lei, de leis esparsas e da Constituição Federal, que, se analisados sistematicamente, remetem à outra interpretação.

Para iniciar a análise, importante mencionar o princípio da preservação da empresa contido no artigo 47 da Lei de Recuperação de Empresas e Falências (LREF), que determina:

Art. 47. A recuperação judicial tem por objetivo viabilizar a superação da situação de crise econômico-financeira do devedor, a fim de permitir a manutenção da fonte produtora, do emprego dos trabalhadores e dos interesses dos credores, promovendo, assim, a preservação da empresa, sua função social e o estímulo à atividade econômica.

Em regra, quando uma empresa se apresenta em situação de crise, esta se encontra debilitada das mais variadas formas, podendo ser de ordem econômica, financeira e patrimonial, ou mesmo uma cominação entre elas. Segundo Coelho (2015, p. 241-242), a crise é de ordem econômica quando há uma retração considerável nos negócios desenvolvidos pela sociedade empresária, podendo ser generalizada, segmentada ou atingir uma única companhia. É de ordem financeira quando a sociedade não possui recursos em caixa para fazer frente aos seus compromissos. Atinge a liquidez do negócio, mesmo tendo aumentado o seu faturamento e a lucratividade, porém, por decisões de investimentos ou por uma crise cambial, por exemplo, ela se encontra endividada a ponto de comprometer a pontualidade de seus pagamentos. A crise de ordem patrimonial é a insuficiência de ativos para honrar os passivos, ou seja, caso a sociedade empresária vendesse todos os seus bens e direitos para 
pagar suas dívidas, haveria insuficiência de ativos para tanto, levando a um quadro de patrimônio líquido negativo e de grande risco aos credores, pois estes tendem a não mais receber a integralidade de seus créditos.

Quanto a sociedade empresária se encontra em uma dessas situações, ou na combinação de algumas delas, decidindo por buscar a proteção legal por intermédio da recuperação judicial, evitando a sua quebra, ela tem urgência na obtenção dessa medida. A perícia prévia vem sendo um obstáculo nesse caminho, retardando, ou mesmo impedindo, de forma indevida, o despacho decisório que proferirá o deferimento do processamento da recuperação judicial, deixando a empresa sem proteção necessária para evitar a expropriação e/ou constrição de seus bens.

Tão logo haja a informação de que a empresa buscou o socorro judicial, mas este ainda não lhe foi concedido, pendente de perícia prévia e do despacho proferindo o deferimento, haverá um movimento por parte dos credores na tentativa de protegerem ou satisfazerem seus créditos. Mesmo havendo a estipulação de prazos curtos para a entrega do laudo da perícia prévia, 5 dias, segundo o Dr. Daniel Carnio Costa, um dos precursores da ideia da perícia prévia para o deferimento do processamento, há os prazos de publicação da nomeação do expert, prazo para a aceitação do encargo, e em alguns casos para formulação de proposta de honorários, intimação da empresa para depositar os valores, prazo para execução dos serviços, prazo para o Juiz analisar o laudo, entre outros, passando facilmente de 30 dias o momento em que se proferirá o despacho decisório deferindo ou indeferindo o processamento da recuperação. Esse prazo estendido pode ser fatal em muitos casos, v. g., quando a sociedade empresária solicita liminares para evitar o corte no fornecimento de energia elétrica, água, telefone, etc. A não concessão dessas liminares pode levar à paralisação das atividades, complicando ainda mais o combalido fluxo de caixa da companhia, podendo ser, inclusive, fator decisivo entre a recuperação ou a quebra do negócio.

É de conhecimento, ainda, que o prazo de 5 dias para realização da perícia prévia não é utilizado por muitos magistrados, pois inviável, estipulando, em regra, prazos de 10 a 30 dias, em média, o que pode levar o momento do despacho decisório para mais de 60 dias da data do protocolo. Trata-se de uma eternidade para uma empresa em crise.

Essa situação é facilmente comprovada pela análise do processo que tramita na Comarca de Barra Velha, em Santa Catarina, sob o número 0300841-02.2018.8.24.0048, que trata do pedido de recuperação judicial da empresa Arxo Industrial do Brasil S/A., cujo 
protocolo ocorreu no dia 03/05/2018, sendo que no dia 07/06/2018 nomeou, em substituição ao expert anterior que declinou do encargo, novo profissional, determinando, in verbis:

2. Tendo em vista o declínio da nomeação anterior, informado à página 549 , NOMEIO, em substituição, a empresa CONTAX CONTABILIDADE E PLANEJAMENTO TRIBUTÁRIO S/S LTDA - EPP, inscrita no CNPJ sob o $\mathrm{n}$. 01.557.465/0001-00, com sede na rua Bolívia, n. 585, térreo, Bairro Ponta Aguda, Blumenau, telefone (47) 3037-3474.

2.1. Intime-se a empresa acima nomeada para, em 5 dias, dizer se aceita o encargo com o objetivo específico de informar ao Juízo se, analisando os dados contábeis da pessoa jurídica e os documentos descritos na forma do artigo 51, inciso II, da Lei 11.101, de 9 de fevereiro de 2005, além dos demais elementos que se fizerem necessários, é possível afirmar que o deferimento da recuperação judicial, com alguma das medidas elencadas no artigo 50 da lei em apreço, permitirá a requerente a sua reestruturação econômica ou se não haverá viabilidade econômica para tanto, informando a sua proposta de honorários periciais, em sendo o caso.

2.2. Informado se aceita o encargo, bem como os honorários periciais, intime-se a requerente para o depósito, em 5 dias.

2.3. No caso concreto, haja vista a sua complexidade, fixo o prazo improrrogável para entrega do laudo em 15 dias.

2.4. Entregue o laudo, intime-se a requerente para manifestação, em 5 dias. Após, retornem os autos imediatamente conclusos para decisão da fila Conclusos Urgente.

Cumpra-se com brevidade. ${ }^{16}$

Mais de 30 dias se passaram e ainda não havia a aceitação de um perito para a realização da perícia prévia, sendo que do despacho é possível extrair quanto tempo ainda poderia levar para se ter a proteção legal com o deferimento do processamento. São 5 dias para o novo expert dizer se aceita o encargo, mais 5 dias para que a requerente concorde e realize o pagamento dos honorários profissionais, mais 15 dias para a realização da perícia e entrega do laudo, e mais 5 dias para que a requerente se manifeste sobre ele, vindo então concluso para a fila dos urgentes para que o Juiz profira o despacho deferindo ou não o pedido de recuperação. Ou seja, podemos concluir que poderiam ser mais 30 dias de prazos previamente estipulados, para então o processo seguir concluso para o Juiz, que ainda teria os seus "dias de urgência" para proferir uma decisão.

Para uma visão mais detalhada dos principais atos do referido processo, segue quadro sinótico:

16 Os grifos são nossos. 


\begin{tabular}{|c|c|c}
\hline Data do Ato & $\begin{array}{c}\text { Data da } \\
\text { Publicação }\end{array}$ & Descrição \\
\hline $03 / 05 / 2018$ & $23 / 05 / 2018$ & protocolo pedido de RJ \\
\hline $18 / 05 / 2018$ & - & $\begin{array}{c}\text { emenda à inicial e nomeação do perito } \\
\text { tutela incidental de urgência em caráter } \\
\text { incidental (Celesc) }\end{array}$ \\
\hline $21 / 05 / 2018$ & - & concessão tutela incidental \\
\hline $01 / 06 / 2018$ & - & neclinação do expert nomeado \\
$07 / 06 / 2018$ & $11 / 06 / 2018$ & nomeação novo expert \\
$12 / 06 / 2018$ & - & apresentação proposta de honorários \\
$04 / 07 / 2018$ & - & apresentação do laudo pericial \\
$05 / 07 / 2018$ & - & manifestação ao laudo \\
$11 / 07 / 2018$ & $17 / 07 / 2018$ & deferido processamento da RJ \\
\hline
\end{tabular}

É possível observar que, entre a data do protocolo do pedido de recuperação judicial e o seu deferimento, considerando a data da publicação, quando efetivamente a decisão do Juiz é inserida no mundo jurídico, passaram-se exatamente 75 dias sem que a sociedade empresária obtivesse a proteção legal, prazo superior ao destinado para a empresa apresentar o plano de recuperação, que é de 60 dias, obrigando, ainda, a requerente a protocolar processo de tutela incidental de urgência para manter o fornecimento de energia elétrica pela concessionária catarinense (Celesc). E, ainda, supondo que o novo expert também tivesse declinado do encargo, a demora poderia se estender para mais de 90 dias, ou seja, algo inadmissível, considerando a urgência da demanda.

A demora na concessão do deferimento do processamento vai de encontro ao princípio da preservação da empresa, norteador de todo o procedimento de recuperação judicial instituído pela Lei n. 11.101/05, Lei de Recuperação de Empresas e Falências. Nesse caso concreto, foram 75 dias entre o protocolo e a publicação do deferimento, mas há casos com prazos menores, porém em todos há um agravamento da situação do devedor, que não obtém a proteção legal na brevidade que um pedido de recuperação judicial necessita.

A alegação desse princípio já seria suficiente para afastar qualquer interpretação pela necessidade da perícia prévia, porém juízes, orientados pela Corregedoria Nacional de Justiça, vêm adotando a prática. Em Santa Catarina, a Corregedoria-Geral de Justiça editou a Circular n. $60^{17}$, de 8 de junho de 2016, recomendando que "nas ações de recuperação judicial seja instituída perícia prévia ao deferimento do processamento da recuperação judicial, visando verificar a viabilidade da empresa como pressuposto lógico e processual para a existência da ação". Isso é uma afronta ao princípio da preservação da empresa instituído no artigo 47 da

17 Poder Judiciário de Santa Catarina. Circular n. 60 da Corregedoria-Geral de Justiça. Disponível em: <http://busca.tjsc.jus.br/buscatextual/index.jsp?cdSistema=41\#resultado_ancora>. Acesso em: 11 set 2018. 
Lei de Recuperação de Empresas e Falências.

Outro argumento utilizado para justificar a perícia prévia é que o instituto recuperacional se destina para empresas viáveis, que possam ser recuperadas, pois, para as irrecuperáveis, há o instituto da falência. Em análise perfunctória, esse argumento aparenta ser verdadeiro, mas como saber se a empresa é ou não recuperável, bem como se o mercado não tem interesse em recuperá-la? A resposta a essa pergunta é de complexidade ímpar, e não será em numa perícia prévia que um expert, por mais competente que seja, dentro de um prazo exíguo de 5 dias, conforme entendimento do Juiz precursor da medida, Dr. Daniel Carnio Costa, conseguirá responder a tais questionamentos.

Mesmo que fosse apenas para uma mera verificação documental e seu conteúdo, visitação in loco, o que não é o caso, pois a Circular n. 60 da Corregedoria-Geral de Justiça de Santa Catarina, sob orientação da Corregedoria Nacional de Justiça, deixou bem claro que o objetivo a ser perseguido pela perícia prévia é verificar a viabilidade da empresa como pressuposto lógico e processual para a existência da ação, o prazo de 5 dias seria exíguo.

Pelo posicionamento da Corregedoria Nacional de Justiça, seguido pela catarinense, bem como pelo despacho decisório acima apresentado da empresa Arxo Industrial do Brasil S/A., a viabilidade da empresa como pressuposto lógico e processual para existência da ação não se atém apenas ao formalismo dos documentos elencados no artigo 51 da Lei n. 11/101/05, e sim vai além. Para poder identificar se a empresa é merecedora da utilização do instituto recuperacional, necessário se faz adentrar em análises econômico-financeiras mais complexas, bem como conhecer das estratégias da companhia, pois uma empresa poder ter números em Balanços extremamente ruins, mas ser detentora de uma patente que envolve uma descoberta científica, ou mesmo de um produto revolucionário que poderá torná-la viável muito rapidamente. Essas análises somente podem ser realizadas, porém demandam muito tempo, levando até meses para se chegar à conclusão da viabilidade ou não da empresa.

Assim, o argumento de que o instituto recuperacional deve ser direcionado para as empresas recuperáveis tem sentido, porém a perícia prévia jamais poderá concluir com esmero se a sociedade empresária conseguirá ou não se recuperar realizando uma perícia prévia em um prazo de 5,15 ou 30 dias.

Caso a empresa, ainda, pelas análises preliminares dos documentos trazidos aos autos, demonstre uma fragilidade econômico-financeira que leva a concluir que o melhor caminho seria a falência, então, a pergunta que se faz, é: por que até o momento nenhum 
credor solicitou sua falência? Será que eles entendem que a empresa ainda se recuperaria? Essas questões somente podem ser resolvidas dentro de um processo de recuperação judicial, o qual, segundo os prazos estipulados em lei, não ultrapassariam 150 dias (art. 56, § $1^{\circ}$ da Lei n. 11.101/05) para se saber o destino da empresa, que seria decidido em assembleia-geral de credores para fins de avaliação do plano de recuperação apresentado pela devedora.

Ou seja, dentro desse prazo ideal, que deveria ser obedecido, mas é reiteradamente desrespeitado pelo próprio judiciário, a manutenção de uma empresa que não foi objeto de pedido de falência por parte dos credores, que são os maiores interessados na recuperação dos créditos, não seria merecedora de utilizar o instituto da recuperação judicial? Aparentemente os credores entendem que ela é recuperável, pois não optaram até aquele momento em solicitar a sua falência.

E, sem esgotar a questão, caso os credores entendam que ela deva ser retirada do mercado, em 150 dias (5 meses) isso seria realidade, momento no qual estaria traçado o seu destino pelos maiores interessados, e não pelo Juiz, que decidirá com base em perícia prévia apresentada por expert, em prazo que não lhe permite uma boa avaliação para identificar se a empresa é ou não merecedora da recuperação.

E caso os credores resolvessem perdoar integralmente o crédito que possuíssem junto à devedora, colocando-a novamente no mercado, e cuja perícia prévia fosse pela não concessão da recuperação devido a debilitada saúde financeira que apresenta? O perdão da dívida é um direito disponível aos credores, mesmo que por maioria em assembleia em um processo de recuperação judicial, pois a lei faculta essa possibilidade. Nesse caso, a perícia prévia traçaria um destino para a empresa diferente do que a maioria de seus credores gostaria.

Não aceitar a recuperação, devolvendo-a ao mercado para que a empresa utilize o instituto correto ou a sua própria sorte, nada agrega; pelo contrário, veda o seu acesso à justiça, o que é proibido constitucionalmente (inciso XXXIV, artigo $5^{\circ}$, Constituição Federal de 1988). Como se trata de uma relação de ordem privada e com atores que conhecem as regras do jogo, não cabe ao judiciário tomar uma decisão em seu lugar.

Outro argumento utilizado para justificar a perícia prévia é o da correta interpretação do caput do artigo 52, o qual determina que, estando em termos a documentação exigida no artigo 51, o Juiz deferirá o processamento da recuperação. Trata-se de texto legal de fácil interpretação, que não demanda grandes esforços hermenêuticos, remetendo apenas ao 
simples cotejamento dos documentos apresentados com os incisos I a IX do artigo 51 da Lei de Recuperação de Empresas e Falências. Porém, justifica-se a necessidade da perícia sob a perspectiva de que deve ser realizada uma verificação do conteúdo desses documentos, sua consistência e correspondência com a realidade fática da empresa, que estaria em consonância com a teoria hermenêutica da superação do dualismo pendular, que visa proteger os dois polos da relação de direito material (COSTA, 2018).

Porém, o legislador não estava preocupado nesse momento com o conteúdo dos referidos documentos, os quais, em momento oportuno, serão analisados tanto pelo Administrador Judicial nomeado, bem como pelos credores, os verdadeiros destinatários das referidas informações. Caso a documentação apresentada contenha irregularidades, há na lei capítulo destinado especificamente para punir atos fraudulentos que resultem em prejuízos aos credores, conforme podemos verificar nos artigos 168 e seguintes da Lei n. 11.101/05, in verbis:

Art. 168. Praticar, antes ou depois da sentença que decretar a falência, conceder a recuperação judicial ou homologar a recuperação extrajudicial, ato fraudulento de que resulte ou possa resultar prejuízo aos credores, com o fim de obter ou assegurar vantagem indevida para si ou para outrem.

Pena - reclusão, de 3 (três) a 6 (seis) anos, e multa.

Aumento da pena

$\S 1^{\circ}$ A pena aumenta-se de $1 / 6$ (um sexto) a $1 / 3$ (um terço), se o agente:

I - elabora escrituração contábil ou balanço com dados inexatos;

II - omite, na escrituração contábil ou no balanço, lançamento que deles deveria constar, ou altera escrituração ou balanço verdadeiros;

III - destrói, apaga ou corrompe dados contábeis ou negociais armazenados em computador ou sistema informatizado;

IV - simula a composição do capital social;

V - destrói, oculta ou inutiliza, total ou parcialmente, os documentos de escrituração contábil obrigatórios.

Contabilidade paralela

$\S 2^{\circ}$ A pena é aumentada de $1 / 3$ (um terço) até metade se o devedor manteve ou movimentou recursos ou valores paralelamente à contabilidade exigida pela legislação.

Concurso de pessoas

$\S 3^{\circ}$ Nas mesmas penas incidem os contadores, técnicos contábeis, auditores e outros profissionais que, de qualquer modo, concorrerem para as condutas criminosas descritas neste artigo, na medida de sua culpabilidade. [...]

Art. 169. Violar, explorar ou divulgar, sem justa causa, sigilo empresarial ou dados confidenciais sobre operações ou serviços, contribuindo para a condução do devedor a estado de inviabilidade econômica ou financeira: [...]

Art. 170. Divulgar ou propalar, por qualquer meio, informação falsa sobre devedor em recuperação judicial, com o fim de levá-lo à falência ou de obter vantagem: [...]

Art. 171. Sonegar ou omitir informações ou prestar informações falsas no processo de falência, de recuperação judicial ou de recuperação extrajudicial, com o fim de induzir a erro o juiz, o Ministério Público, os credores, a assembleiageral de credores, o Comitê ou o administrador judicial: [...] 
Art. 172. Praticar, antes ou depois da sentença que decretar a falência, conceder a recuperação judicial ou homologar plano de recuperação extrajudicial, ato de disposição ou oneração patrimonial ou gerador de obrigação, destinado a favorecer um ou mais credores em prejuízo dos demais: [...]

Art. 173. Apropriar-se, desviar ou ocultar bens pertencentes ao devedor sob recuperação judicial ou à massa falida, inclusive por meio da aquisição por interposta pessoa:

$[\ldots]^{18}$

Desta forma, não há motivos para se preocupar, previamente, com o conteúdo dos documentos apresentados pela devedora no ato do pedido da recuperação judicial. Essa obrigação é naturalmente investida ao Administrador Judicial, bem como de responsabilidade igual dos credores, que precisam se certificar que os dados apresentados pela recuperanda correspondem à sua realidade fática. Todos os profissionais envolvidos na geração de informações fraudulentas respondem penalmente nos termos da Lei n. 11.101/05, sejam eles contadores, administradores, auditores, consultores, entre outros profissionais.

Isto leva a concluir, também, que o advogado que patrocina a causa tem sua parcela de responsabilidade, pois deve se certificar com os demais profissionais envolvidos em um projeto de recuperação judicial que aquelas informações, mesmo não sendo de sua expertise, são fidedignas, que não tenham potencial de prejudicar terceiros, ou seja, deve ele aplicar regras de compliance jurídico para evitar possíveis fraudes.

$\mathrm{O}$ argumento de que a perícia prévia deve averiguar o conteúdo da documentação previamente também não tem como prosperar, pois a Lei de Recuperação de Empresas e Falências traz capítulo específico sobre fraude cometida contra credores na recuperação judicial, extrajudicial e na falência. O não deferimento de um pedido de recuperação judicial fundado na perícia prévia, sob o argumento de que os documentos não espelham a realidade, devolveria ao mercado uma empresa problemática e cujos representantes e demais profissionais envolvidos na geração de informações fraudulentas não seriam punidos.

Portanto, indevida e ilegal a utilização da perícia prévia como requisito anterior para o deferimento do processamento da recuperação judicial, sendo contrário, especialmente, ao princípio da preservação da empresa, bem como de outras regras legais destinadas aos envolvidos em processos de recuperação judicial.

\section{CONSIDERAÇÕES FINAIS}

${ }^{18}$ Grifos nossos. 
A instituição da perícia prévia como requisito para o deferimento do processamento da recuperação judicial, nada mais é do que um novo capítulo da crise de jurisdição vivenciada nos dias atuais. Assumiu o Juiz papel de legislador, sob as alegações de que estaria interpretando a norma dentro de um contexto a ela destinada, possibilitando que apenas as empresas merecedoras da recuperação utilizem o instituto, pois, para as demais, o caminho seria o pedido de falência.

Porém, essa assertiva é facilmente afastada. Inicialmente pela impossibilidade de uma perícia prévia realizada em curto espaço de tempo, apresentar conclusões precisas sobre a situação da viabilidade da empresa se recuperar. Mesmo sendo a perícia apenas uma análise dos documentos trazidos aos autos, esse prazo também seria exíguo, dependendo do porte da empresa a ser avaliada. Também não podemos olvidar que a análise documental, nesse caso, é mister do Juiz, pois não lhe é exigido conhecimento de seu conteúdo, apenas a verificação se estão todos presentes, pois a lei traz penalidades caso as informações sejam fraudulentas. Ocorre, ainda de o perito não ter como avaliar as intenções dos credores em relação à empresa, pois, se estes desejassem sua quebra, provavelmente já teriam realizado um pedido de falência. Assim, não é prudente o Juiz decidir pelos credores, pois poderiam eles abdicar de parcela significativa dos seus créditos, conceder prazos de pagamento extremamente longos, carência, entre outras formas de recuperação, que viabilizem novamente seu cliente, bem como este ser detentor de algum invento, cujo potencial de geração de caixa futuro não estará representado nos balanços que instruem o processo, comprometendo as conclusões da perícia prévia e a decisão do Juiz. Todas essas variáveis somente podem ser tratadas, com a atenção necessária, dentro de um plano de recuperação judicial devidamente negociado com os credores.

Outra questão que afasta o entendimento da necessidade da perícia prévia, é o princípio da preservação da empresa, mitigado pelo excesso de prazo ocasionado pelo pedido de perícia, impossibilitando-a de auferir o benefício do stay period, que suspende todas as ações e execuções contra o devedor, evitando, especialmente, expropriações de bens da empresa e a dificuldade daí decorrente para a manutenção das suas atividades. No caso avaliado neste estudo, o da empresa Arxo Industrial do Brasil S/A., o prazo entre o pedido de recuperação e a publicação do despacho decisório deferindo o processamento, momento em que se inicia a proteção legal, foi de 75 dias, ou seja, prazo superior ao estipulado pela lei para 
apresentação do plano de recuperação judicial e metade do prazo para a realização da assembleia (150 dias).

O caminho mais curto para retirar as empresas inviáveis do mercado, caso estas não peçam autofalência, seria via assembleia de credores para avaliação do plano de recuperação judicial apresentado. Rejeitado o plano, convola-se em falência, isso num curto espaço de tempo estabelecido pela lei.

Portanto, a interpretação que vem sendo adotada pelos Juízes que atuam nos processos de recuperação judicial, sob orientação da Corregedoria Nacional de Justiça, é ativismo judicial, pois não tem previsão legal, bem como a interpretação utilizada para sua exigência está fora da moldura interpretativa que a norma oferece.

\section{REFERÊNCIAS}

BRASIL. Constituição Federal, de 5 de outubro de 1988.

BRASIL. Código Civil, Lei n. 10.406, de 10 de janeiro de 2002.

BRASIL. Lei de Falências, Decreto-lei n. 7661, de 21 de junho de 1945.

BRASIL. Lei de Recuperação de Empresas, Lei n. 11.101, de 9 de fevereiro de 2005.

CAPPELLETTI, Mauro. Juízes Legisladores? Porto Alegre: Sérgio Antônio Fabris Editor, 1993.

CASTRO, Carlos Alberto Farracha de. Preservação da Empresa no Código Civil. Curitiba: Juruá, 2010.

COASE, Ronald Harry. A Firma, o Mercado e o Direito. 2a ed. Rio de Janeiro: Forense Universitária, 2017.

COELHO, Fábio Ulhoa. Curso de Direito Comercial: Contratos, Falência e Recuperação de

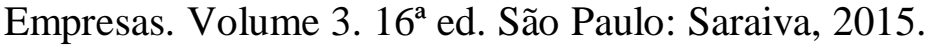

COSTA, Daniel Carnio. A perícia prévia em recuperação judicial de empresas - Fundamentos e aplicação prática. Migalhas, 2018. Disponível em: <https://www.migalhas.com.br/InsolvenciaemFoco/121,MI277594,41046-

A+pericia+previa+em+recuperacao+judicial+de+empresas+Fundamentos+e>. Acesso em: 07 set 2018.

FURTADO, Paulo. Perícia prévia na recuperação judicial: a exceção que virou regra? Migalhas, 2018.

Disponível em: 
<http://www.migalhas.com.br/InsolvenciaemFoco/121,MI279351,71043-

Pericia+previa+na+recuperacao+judicial+a+excecao+que+virou+regra $>$. Acesso em: 08 set 2018.

GRAU, Eros Roberto. A ordem econômica na Constituição de 1988. $18^{\mathrm{a}}$ ed. São Paulo: Malheiros, 2017.

HORTA, Raul Machado. Estudos de Direito Constitucional. Belo Horizonte: Del Rey, 1995.

KELSEN, Hans. Teoria Pura do Direito. São Paulo: WMF Martins Fontes, 2009.

LOBO, Jorge; TOLEDO, Paulo F. C. Salles de; ABRÃO, Carlos Henrique; et al. Comentários à Lei de Recuperação de Empresas e Falência. $5^{\text {a }}$ ed. São Paulo: Saraiva, 2012.

Poder Judiciário de Santa Catarina. Circular n. 60 da Corregedoria-Geral de Justiça. Disponível em: <http://busca.tjsc.jus.br/buscatextual/index.jsp?cdSistema=41\#resultado_ancora>. Acesso em: 11 set 2018.

SZTAJN, Rachel. Teoria Jurídica da Empresa: atividade empresária e mercados. $2^{\mathrm{a}}$ ed. São Paulo: Atlas, 2010.

WARDE JÚNIOR, Walfrido Jorge. Tratado de Direito Empresarial: I - Teoria Geral da Empresa. São Paulo: Revista dos Tribunais, 2016. 